\title{
Effect of Heat Treatment on the Corrosion Behaviour of Rapidly Solidified Al-8Ni-2Co
}

\author{
Alloy in $\mathrm{NaCl}$ Solution

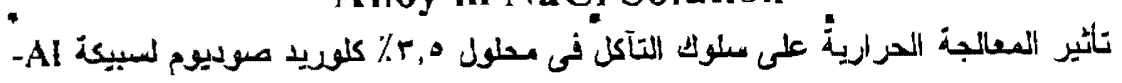 \\ 8Ni-2Co \\ ${ }^{\star}$ F.N. El-Sabbahy, ${ }^{\star}$ M.A. Kussem, ${ }^{*}{ }^{\star}$ R.M. Ramadan \\ * Lecturer **Associate Prof. \\ Dept. of Metallurgy, Faculty of Pet. \& Min. Eng., \\ Suez Canal Univ., Suez, Egypt.
}

$$
\text { خلاصسـة عزيى : }
$$

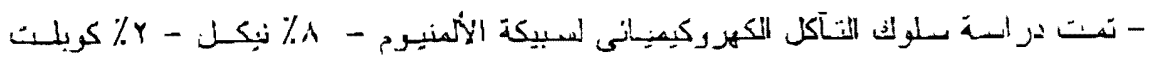

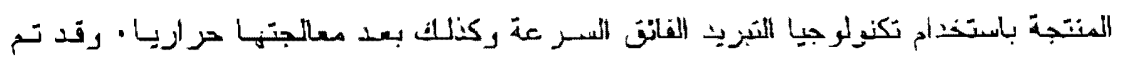

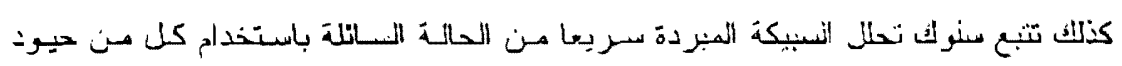

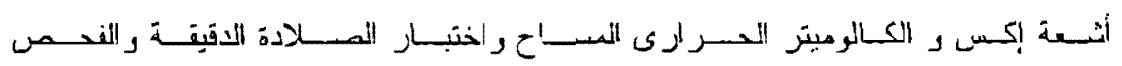

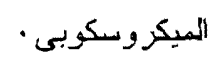

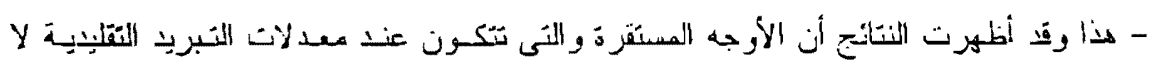

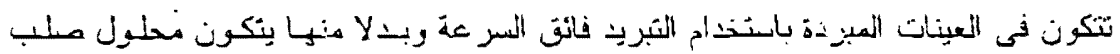

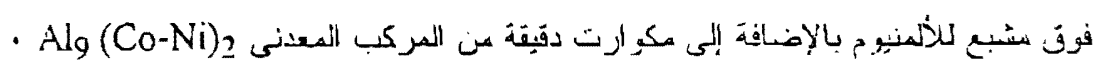

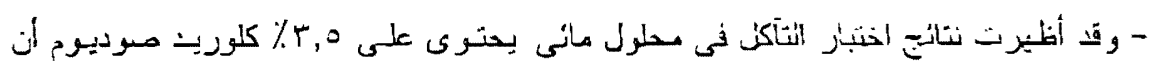

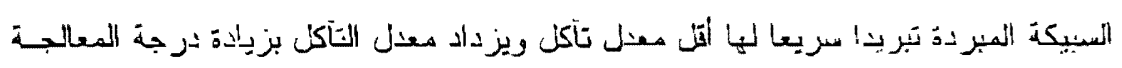

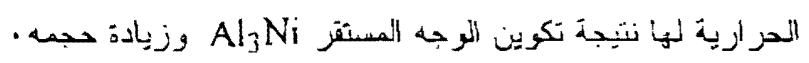

\section{Abstract :}

The corrosion behaviour of as-rapidly solicified and heat treated AI$8 \mathrm{Ni}-2 \mathrm{Co}$ alloy ribbons produced using meit spiming technique was investigated. The decomposition behaviour of the rapidly solidified ribbons was followed up using $x$-ray diffraction, differentialscanmingcalometry, microhardness, and metallography. The stable phases which are grenerally formed in conventional solidified alloy in the as cast condition, were not detected in the as-rapidly solidified specimens. Instead, super-saturated solid solution $\alpha-A$ l was present in addition to fine dispersoids of $\mathrm{Al}_{9}(\mathrm{CoNi})_{2}$. The corrosion behaviour was investigated through potentiostatic technique in $3.5 \% \mathrm{NaCl}$ aqueous solution. The corrosion rate was the lowest in the as-rapidly solidified condition and increased with increasing the annealing temperature as a result of the fonnation and coarsening of the intermetallic $\mathrm{Al}_{3} \mathrm{Ni}$. 


\section{Introduction :}

Although it is generally agreed that aluminium alloys acquire good corrosio resistance ta marine environments, many are susceptible to localized corrosion [1-3]. Micro-constituents are usually the source of most problems with electrochemical corrosion as they lead to localized attack resulting from the potential difference between the microconstinuents and the aluminium matrix. Therefore a solid solution is the most corrosion resistance form in which an alloy may exist. Rapid solidification extends the solid solubility with a consequent homogeneous distribution of dispersoids in addition to the formation of microcrystalline alloys. Thereto, the corrosion behaviour of rapidly solidified aluminiun alloys is of interest in connection with the formation of alloys in which the solid solubility is extended. Through the use of controlled rapidly solidified particulate [4] or flakes [5] and fabrication techniques: it is possible to obtain products with high volume fractions of finely-dispersed intermetallic phases. On one hand, these particles impar strength through dispersion strengthening and thermal stable structure through utilizing alloying additions with high liquid solubility, low' solid solubility and low diffusion coefficients in the aluminium matrix [6-8]. On the other hand, the corrosion behaviour of these wrought $P / M$ alloy products mav be imparied or improved depending on the potential difference between the evolved dispersoids and the aluminium matrix.

Annong rapidly solidified aluminium alloys, Al-Ni-Co alloys have been reported to be potential candidates for high temperature applications. In such alloys the inain dispersoids evolved during aging or fabrications are $\mathrm{Al}_{3} \mathrm{Ni}$ and $\mathrm{Al}_{9}(\mathrm{Co}, \mathrm{Ni})_{2}[6-8]$.

The purpose of the present work is to tharactenze the combined effect of rapid solidification and the aging temperature on the decomposition and corrosion characteristics of the Al-8Ni-2Co alloy.

\section{Experimental :}

Al-8Ni-2Co alloys was prepared by arc melting of pure elements on a water cooled copper hearth with a tungesten electrode in a partial pressure of titaniun gettered argon. Rapid quenching from melt ivas performed by induction melting the alloy in a quant tube placed in a helium atmosphere. The melt was then ejected by helium pressure onto a single copper roller with $145 \mathrm{~mm}$ diameter, and rotating at $2200 \mathrm{rpm}$. 
Rapidely quenched ribbons of 5-8 mm widtl and 20-80 pun thick were produced.

Thennal stability of the rapidly solidified ribbons was investigated using several techniques : differential scanning calorimetry (DSC). microhardness measurements and X-ray diffaction (XRD) which was carried out on the wheel side ribbon's surface. The DSC was done by operating the calorineter at constant heating rate of $10^{\circ} \mathrm{C} / \mathrm{min}$ over the temperature range $\left(25-700^{\circ} \mathrm{C}\right)$. The $\mathrm{XRD}$ using $\mathrm{Cu}-\mathrm{K} \alpha$, radiation was performed on Rigaku D-Max diffractometer at a scan speed of $2 \% /$ min and step angle of $0.1^{\circ}$. Vicker's microhardness measurements were made using Schimadzu microhardness testing machine at a load of $25 \mathrm{gnn}$. Microhardness value was taken as an average of ten readings for each sample.

Polarization curves were constructed by a potentiostatic method, using a Wenking Potentioscan (POS 73). The corrosive environinent used was an aerated solution of $3.5 \% \mathrm{NaCl}$ prepared using analar grade chemicals and distilled water. A platinium electrode was used as a counter electrode and all the potentials were measured against saturated calome! electrode (SCE). The working electrode was coated by alcomit lacquer and free surface of $1 \times 1 \mathrm{~cm}^{2}$ of the wheel side surface ivas exposed. The experiments were perfonned in a $250 \mathrm{ml}$ coming glass celi containing 200 Inl of the test solution at room temperature. The specimen was held in the solution, at open circuit potential for 1 lur. for steady statc corrosion potential $\left(\mathrm{E}_{\text {cors }}\right)$ and then cathodic and anodic polarization current were measured potentiostatically. Potential steps of $20 \mathrm{mV}$ for the anodic polarization and $10 \mathrm{mV}$ for the cathodic polarization were applied manually, specimen stabilize for about $5 \mathrm{~min}$, and then current measurements were done. Corrosion rate, in mpy, was computed by extrapolation of the cathodic tafel line to corrosion potential.

\section{Results and Discussion :}

Thermal decomposition of the rapidly solidified materials :

In order to understand the corrosion behaviour of the rapidly solidified material as well as the annealed one, the decomposition behaviour of as rapidly solidified inaterial was investigated. The DSC thermogram of as-melt quenched specimen at a heating rate of $10^{\circ} \mathrm{C} / \mathrm{min}$ up to $700^{\circ} \mathrm{C}$ is shown in Fi.g la. There are two exothermic peaks spaning 
the temperature range of $305-490$ and $510-590$ with peaks maximum at 380 and $554^{\circ} \mathrm{C}$ respectively. The DSC results well agree with the microhardness measurements illustrated in Fig. $\mathrm{lb}$. The as rapidly solidified structire is observed to thermally decompose just above $300^{\circ} \mathrm{C}$ and stabilize over $500^{\circ} \mathrm{C}$,

There are two types of precipitations occure as can be deduced from the DSC results, Fig. la. The $x$-ray that diffraction results display the constituents of the as-rapidly solidified materials at each stage of annealing. The main micro-constituents of the as-rapidly solidified specimen are mainly the super saturated aluminium solid solution and a minor dispersoids of the monoclinic $\mathrm{Al}_{9} \mathrm{CO}_{2}[8,9]$. The intermetallic $\mathrm{Al}_{9} \mathrm{CO}_{2}$ appears to result from direct nucleation from the melt as reported previously [9] and followed by subsequent growth. That can be infered from the increasing of $\mathrm{Al}_{9} \mathrm{CO}_{2}$ peaks and intensity with the annealing temperature, Fig. 2. Because the solubility of nickel in intennetallic $\mathrm{Al}_{9} \mathrm{CO}_{2}$ is extensive, more than two-third of cobalt atoms can be replaced by nickel [10], theseto, the primary intermetallic is $\mathrm{Al}_{9}(\mathrm{Co}, \mathrm{Ni})_{2}$. The $\mathrm{X}$-ray results, Fig. 3. of annealed materials at 300 and $400^{\circ} \mathrm{C}$ for one hour show that the precipitation of metastable $\mathrm{AJ}_{3} \mathrm{Ni}$ (orthorombic . $\mathrm{a}=6.4, \mathrm{~b}$ $=7.56$, and $c=9.56 \mathrm{~A}^{\circ}$ ) [11]. A few weak peaks of the hexagonal $\mathrm{Al}_{5} \mathrm{CO}_{2}$ [12] are detected too. Therefore, the first wide exthothermic peak, Fig. 1, can be assigned to the precipitation of metastable $\mathrm{Al}_{3} \mathrm{Ni}$ and $\mathrm{Al}_{5} \mathrm{CO}_{2}$ and growing of $\mathrm{Al} 9(\mathrm{Co}, \mathrm{Ni})_{2}$. Annealed sample at $500^{\circ} \mathrm{C}$ shows the transformation of inetastable $\mathrm{AL}_{3} \mathrm{Ni}$ to the stabie $\mathrm{Al}_{3} \mathrm{Ni}$ (ortholombic: $a=6.398, b=7.352, c=4.802 \mathrm{~A}^{\circ}$ ) [1.3], Fig. 3. The present phases at each condition are summerized in Table I, which are very important to explain the corrosion behaviour of each material.

\section{Electrochemical behaviour :}

The anodic polarization behaviour of the as-melt quenched and wat annealed at 300,400 , and $500^{\circ} \mathrm{C}$ for one hour was investigated. Fig. 3 . shows the anodic polarization curves for the investigated materials. The characteristics parameters of the anodic behaviour sucl as the free corrosion potential $\left(E_{\text {corr }}\right)$, the critical current $\left(i_{c r i t}\right)$ and passivity current $\left(i_{p}\right)$, break down potential $\left(E_{b . d}\right)$ and passivation range are listed in Table 2. It is observed that with increasing annealing temperature, the corrosion potential, breakdown potential and passivation range decrease, 
while passivation current, critical current and corrosion rate increase. The anodic current density in the region between the open circuit potential and the pitting potential is the lowest for the as-rapidly solidified sample and it increases with increasing the annealing temperature. Such behaviour is strongly related to the decomposition process that takes place during annealing of the as-rapidly solidified materials. The important trend in the electrochemical data, table. 2, indicate that the inicroconstituents, affect the corrosion characteristics of the investigated material. In particular, decomposition of the as-melt quenched microstructure which promote the fornation of stable $\mathrm{Al}_{3} \mathrm{Ni}$ dispersoid. The presence of this phase increase the susceptibility of the Al-8Ni-2Co alloy to attack in $3.5 \% \mathrm{NaCl}$ solution. An understanding of the formation and growth of the intermetallics is central to the understanding of the corrosion belaviour. In order to make this connection as clear as possible a plot of free corrosion potentiat versus annealing temperature which results in a sigmodial curve, Fig. $1 \mathrm{c}$,compared with the decomposition curve deduced by microhardness, Fig. Ib. It indicates that a significant change in corrosion behaviour occurs when the annealing temperature exceeds $300^{\circ} \mathrm{C}$. This coincides with the commence of the decomposition of the as-meit quenched solid solution. The datected phases at each stage of annealing are listed in Table 1. The electrode potential with respect to SCE of the aluminium matrix is -0.85 as compared with -0.52 for stable $\mathrm{Al}_{3} \mathrm{Ni}$ [14]. The dispersoid $\mathrm{Al}_{3} \mathrm{Ni}$ is cathodic with respect to aluminium. Therefore, it provides point at which the surace oxide film is weak, thereby promoting electrochemical attack, pitting corrosion $[1,2,14]$. The effect of precipitation is in turn reflected in the decrease of the pitting potential with the increase of annealing temperature. The rate of general corrosion (mpy) of as-4neit quenched material is much less than that of annealed ones, table. 2, which is attributed to the increasing of the number of small size cathodic $\mathrm{Al}_{3} \mathrm{~N}_{1}$ through the structure.

\section{Conclusions :}

1- Rapid solidification of Al-9Ni-2 Co alloy supresses the formation of the $\mathrm{Al}_{3} \mathrm{Ni}$ phase. Thus only fine $\mathrm{Al},(\mathrm{Co}, \mathrm{Ni})_{2}$ and unstable $\alpha$-Al solid solution are present in the as-rapidly solidified alloy

2- The corrosion results show that rapid solidification is an effective method ennobling the corrosion parameters of the investigated alloy. 
3- The increasing of the overall corrosion rate with increasing the annealing temperature is found to coincide with the decomposition of the super saturated solid solution $\left(\alpha^{\prime}-\mathrm{Al}\right)$ and the formation and coarsening of the cathodic-phase $\mathrm{Al}_{3} \mathrm{Ni}$ make the passivation process less effective.

\section{REFERENCES :}

1- S.M. Skolianos, T.Z. Kattamis and O.F. Devereux, Metall. Trans., 20A (1989) 2499-2515.

2- H. Youshioka et al, Corrosion Sci., 26 (1986) 795-8I2.

3- E.Lunarska, E.Trela, and Z. Szklarska-Smialowska, Corrosion, 43 (1987) 219.

4- N.J.Grant, S.Kang and W.Wang, In. Proc of ISt Int. Al-Li Conf., Eds., T.H. Sanders, Jr. and E.A. Starke.dr., AIME, 1981. 121-188.

5- K.K. Sankaran, S.M.L. Sastry, and J.E. ONeal, Ibid, 189-227

6- Hamish, L.Fraser et al., In "Rapidiy Solidified Powder Al-alloys" ASTM STP 890-, Eds., M.E. Fine and E.A. Starke, Jr, A.STM, Philadelphia, 1986., 186-210.

7- M.W. Griffith, R.E. Sanders, Jr, and G.J. Hildeman, in "High Strength Powder Metallurgy Al-alloys", Eds. M.J. Kazak and G.J. Hildeman. AIME, 1982, 209-224.

8- B.K. Garrett, Jr.and T.H. Sanders, Jr., Mater. Sci. \& Eng., 60 (1983) 269-274.

9- G.Van Tendeloo, J.Menon, and C. Suryanarayana, J.Mater. Res., 2 (1987) 547-556.

10- L.F. Mondolfo, "Aluminium : Structure and properties", Butterworth London, 1976, P. 478.

11- T.R.Anartharaman et al, In "Proc. of 2 nd Int. Conf. RQM, Eds. J.N Grant and B.C. Giessen, 17-19 Nov., 1975 Massachusetts, 157-161.

12- JCPDS card file No. 3-1080.

13- JCPDS card file No. 2-416.

14- I.J. Polmear, "Light Alloys", Edward Arnold, Londoin, 198 I, 30. 
Mansoura Engineering Journal (MEJ), Vol. 20, No. 1, March. 1995. M. 29.

- Table 1. The detected phases in the investigated inaterials.

\begin{tabular}{|c|c|}
\hline Condition & Detected phases \\
\hline $\begin{array}{l}\text { as-melt quenched } \\
\text { annealed at } 300^{\circ} \mathrm{C} / 1 \mathrm{hr} \\
\text { annealed at } 400^{\circ} \mathrm{C} / 1 \mathrm{hr} \\
\text { annealed at } 500^{\circ} \mathrm{C} / 1 \mathrm{hr}\end{array}$ & $\begin{array}{l}\text { super saturated solid solution }\left(\alpha^{\prime}-\mathrm{Al}\right)+\mathrm{Al} l_{9}(\mathrm{Co}, \mathrm{Ni})_{2} \\
\alpha-\mathrm{Al}+\mathrm{A}{ }_{9}(\mathrm{Co}, \mathrm{Ni})_{2} \\
\alpha-\mathrm{Al}+\mathrm{A} \mathrm{J}_{9}(\mathrm{Co}, \mathrm{Ni})_{2}+\text { metastable } \mathrm{Al}_{3} \mathrm{Ni}+\mathrm{Al}_{5} \mathrm{Co}{ }_{2} \\
\alpha-\mathrm{Al}+\mathrm{A} l_{9}(\mathrm{Co}, \mathrm{Ni})_{2}+\text { Stable } \mathrm{Al}_{3} \mathrm{Ni}+\mathrm{Al}_{5} \mathrm{Co}{ }_{2}\end{array}$ \\
\hline
\end{tabular}

Table. 2. Polarization test results for $\mathrm{Al}-8 \mathrm{Ni}-2 \mathrm{Co}$ in $3.5 \% \mathrm{NaCl}$ solution at room temperature

\begin{tabular}{|c|c|c|c|c|c|c|c|}
\hline $\begin{array}{l}\text { Heat } \\
\text { treatments } \\
\text { conditions }\end{array}$ & $\begin{array}{l}E_{\text {corr }} \\
\text { mV V/SCE }\end{array}$ & $\begin{array}{l}E_{b . d} \\
m V / S C E\end{array}$ & $\begin{array}{l}\text { Passivation } \\
\text { mange (mV) }\end{array}$ & $\begin{array}{l}\Delta E_{p} \\
\left(E_{b, d}-E_{c o r r}\right)\end{array}$ & 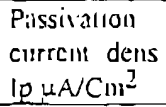 & $\begin{array}{l}\text { crulical }_{2} \\
\text { แAVC.m2 }\end{array}$ & $\begin{array}{l}\text { Corrosinu } \\
\text { rac mips }\end{array}$ \\
\hline $\begin{array}{l}\text { as-rapidly } \\
\text { solidified }\end{array}$ & -717 & -100 & 560 & 817 & 12 & 14 & 85 \\
\hline $300^{\circ} \mathrm{C}$ & -720 & +50 & 450 & 770 & 23 & 35 & 17 \\
\hline $400^{\circ} \mathrm{C}$ & -735 & $\div 20$ & 480 & 755 & 27 & 32 & 19 \\
\hline $500^{\circ} \mathrm{C}$ & -755 & -20 & 380 & 735 & 70 & 85 & 2.3 \\
\hline
\end{tabular}


M. 30 F.N. El-Sabbahy, M.A. Kassem, R.M. Ramadan.
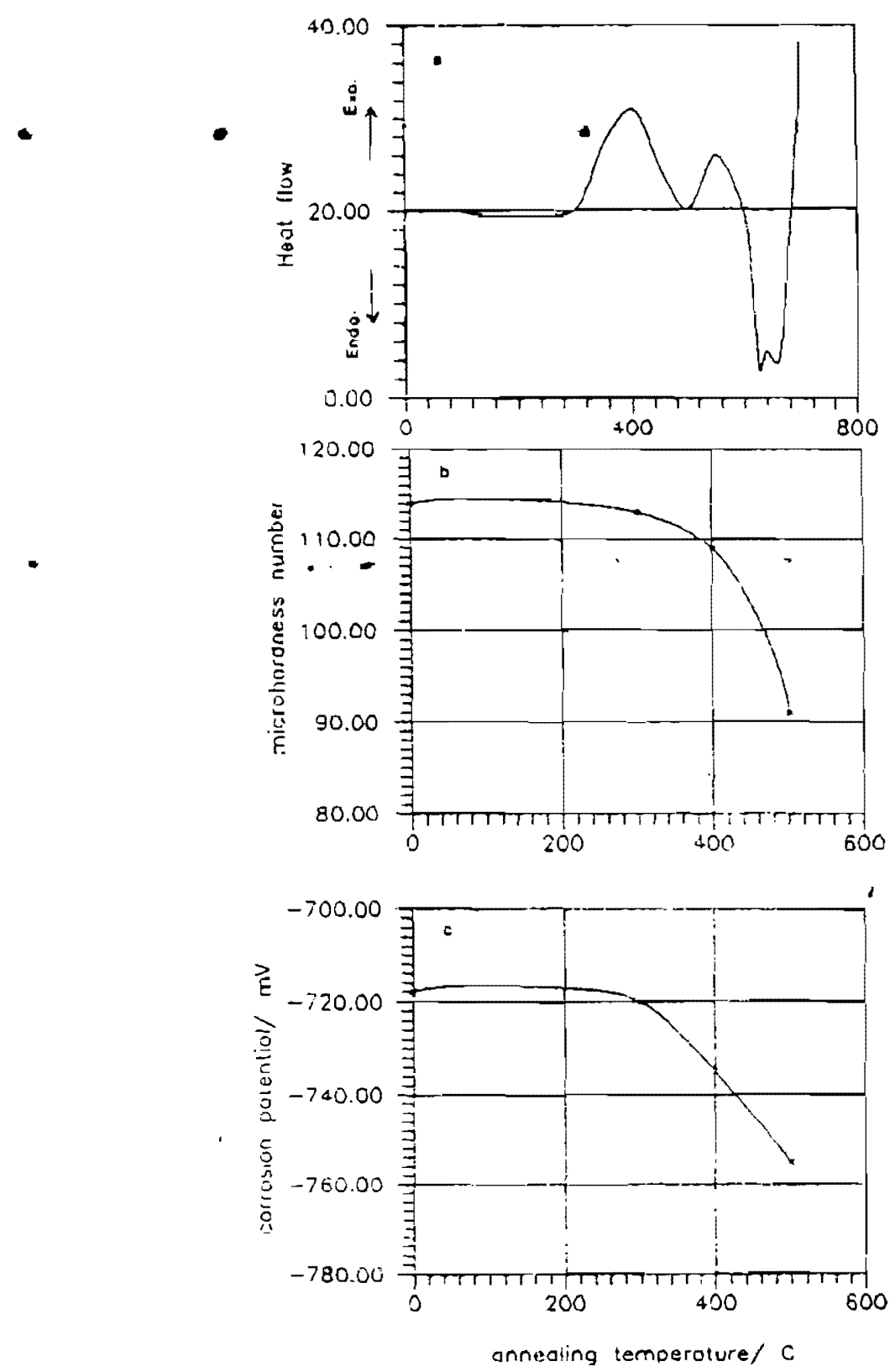

Fig 1 Thermol decomposition response of the us-melt quenched materiols annealing at temperatures of 300. 400 and $500 \mathrm{C}$. for on hour. a) DSC thermogram. (b) microhordness, and c) free corrosion potantial response. 
Mansoura Engineering Journal (MEJ), Vol. 20, No. 1, March. 1995. M. 31.

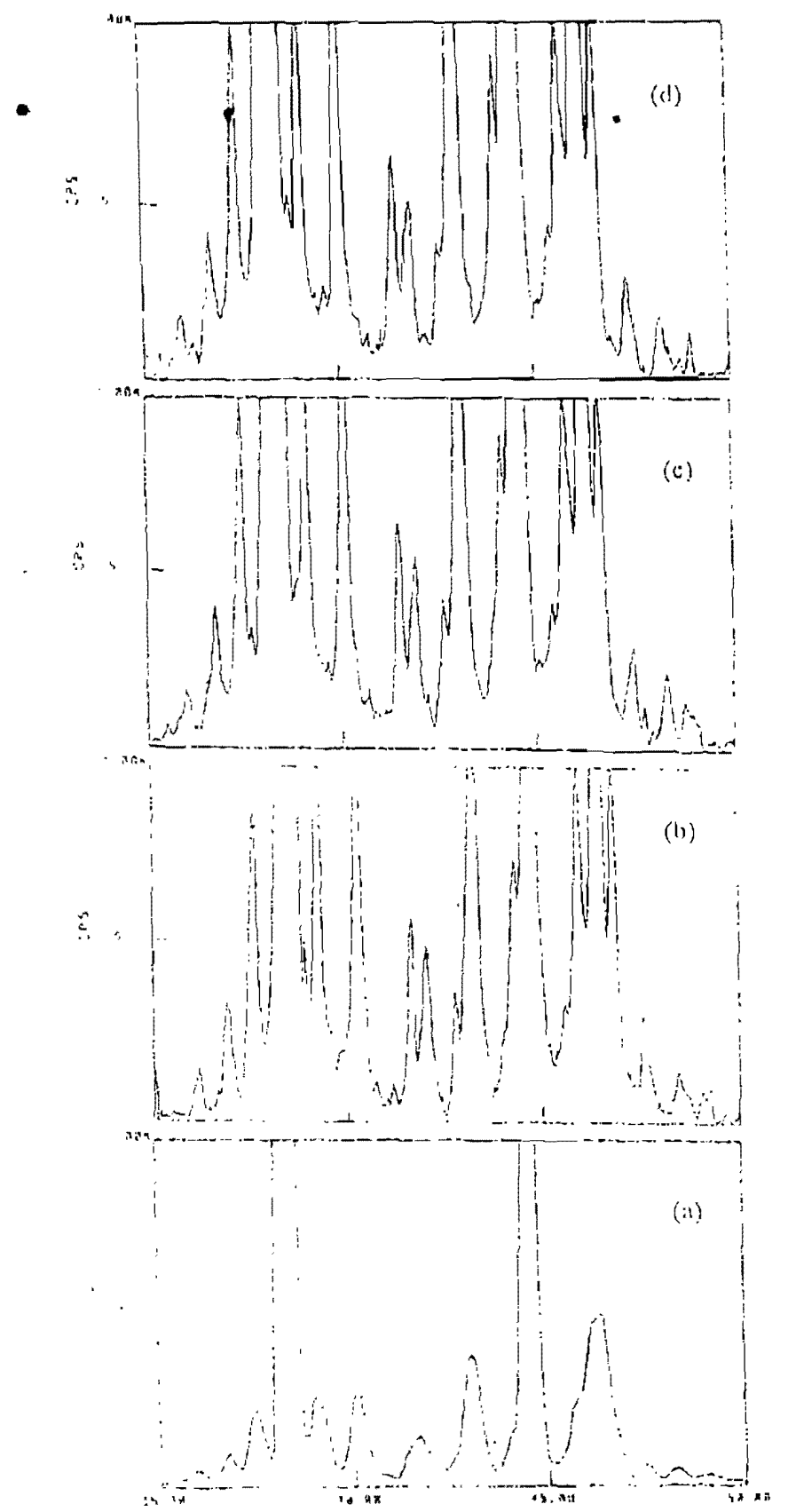

fig. 2 X-ray difraclion of the investigned alloy (a) as-mieli quenclued (h. $a$ and alj anocaling at 300.400 and $500^{\circ} \mathrm{C}$ respectucly for on: trour. 
M. 32 F.N. El-Sabbaly, M.A. Kassem, R.M. Ramadan.

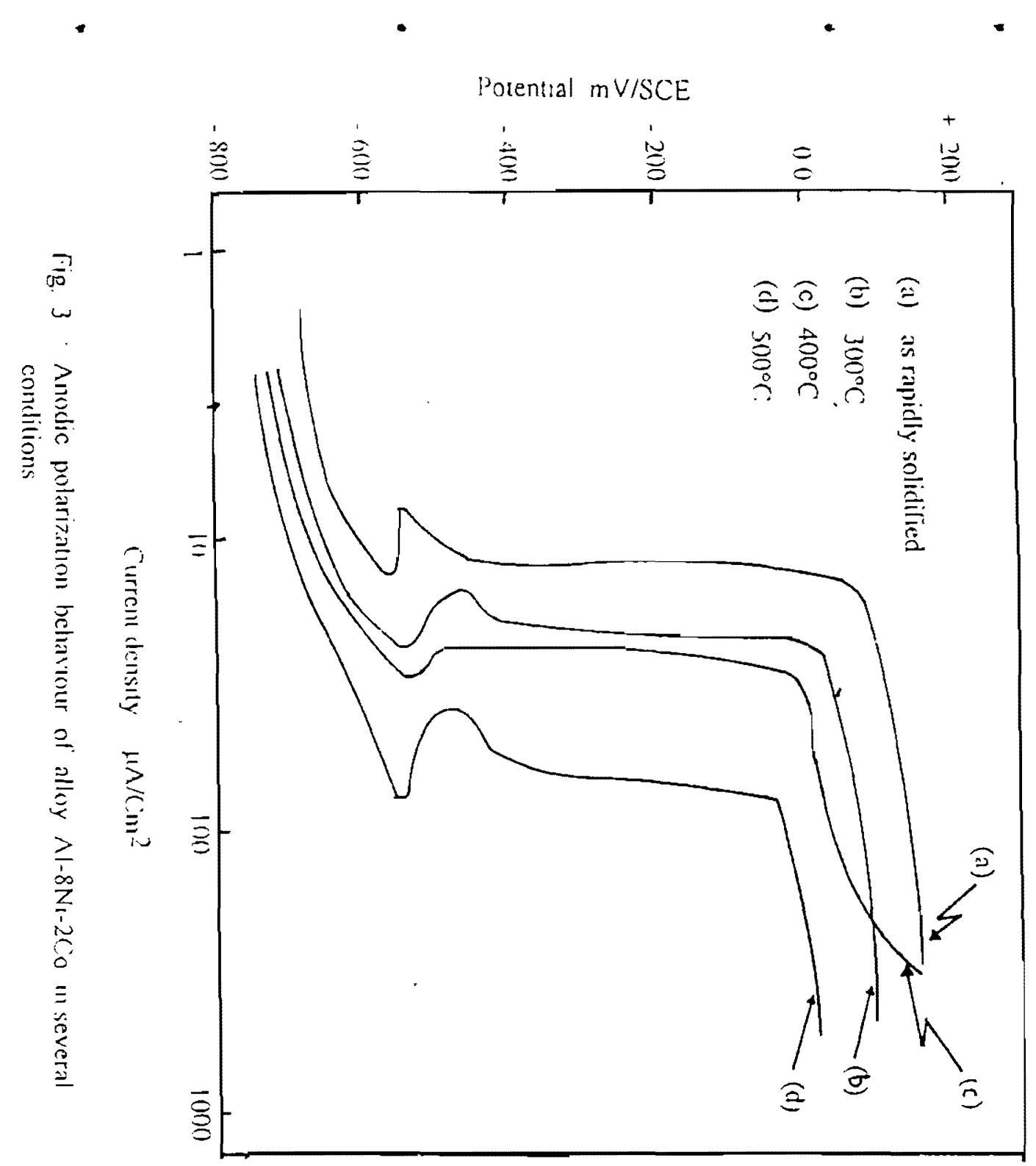

